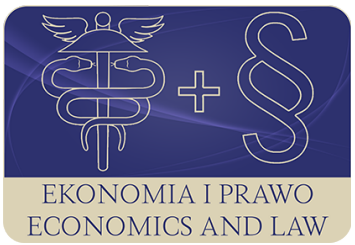

EKONOMIA I PRAWO. ECONOMICS AND LAW

Volume 18, Issue 2, June 2019

p-ISSN 1898-2255, e-ISSN 2392-1625

www.economicsandlaw.pl

ORIGINAL ARTICLE

received 28.07.2018; revised 14.02.2019; accepted 30.06.2019

Citation: Buszko, M., Krupa, D., \& Chojnacka, M. (2019). Young people and banking products and services in Poland: the results of empirical studies. Ekonomia i Prawo. Economics and Law, 18(2): 147-164. doi:10.12775/EiP.2019.012.

\title{
Young people and banking products and services in Poland: the results of empirical studies
}

\section{MICHAE BUSZKO}

corresponding author

Nicolaus Copernicus University in Torun, Faculty of Economic Sciences and Management,

Department of Finance Management, ul. Gagarina 13a, 87-100 Torun, Poland

$\square$ mibus@umk.pl

(iD) orcid.org/0000-0002-1743-1902

DOROTA KRUPA

Nicolaus Copernicus University in Torun, Faculty of Economic Sciences and Management, Department of Finance Management, Poland

$\square$ dkrupa@umk.pl

orcid.org/0000-0001-9765-6871

\section{MALWINA CHOJNACKA}

Independent researcher, Poland

$\square$ m.choj@op.pl

\begin{abstract}
Motivation: Banks tend to offer increasingly innovative, distinctive products, to introduce new sales channels, as well as to search for new customers. A special group, more often served by banks, are young people.

Aim: The main aim of this study is evaluating the types, preferences and patterns of using banking offers as well as to evaluate major channels of accessing banking products and services by children, youths and young adults. The authors used studies of literature, analysed bank products and services for young people as well as conducted survey research on a group of people under 25 years.

Results: Young people represent a primarily multi-product approach and their level of financial knowledge determines the use of modern solutions as well as a high diversity
\end{abstract}


of products. Young people that use banking products and services rarely decide to use offers of other financial institutions.

Keywords: young people; bank products and services; age; gender; education; residence JEL: G2; G41

\section{Introduction}

When trying to achieve a competitive advantage in the financial services market, banks try to offer increasingly innovative, distinctive products and services, to introduce new communication and sales channels, as well as to search for new customers. One of the groups of clients, which are becoming increasingly the object of interest for banks, are young people, including those under the age of 13 years old. Due to the lack of, or small incomes, these people are not the main customer segment for banks but are treated as prospective clients who will use the full range of banking products when they start their professional activity. The motivation behind offering banking services for young people is, above all, a willingness to familiarise and link such persons with the bank in the long term. Such an approach tends to build customer loyalty based on relatively simple but understandable products and services offered mostly through internet or mobile channels. This way of offering is in line with the trend of broad usage of internet and mobile technologies by young people, for whom the permanent use of internet or smartphones forms a specific lifestyle. Adoption of modern bank products and services allows children and youths to become acquainted with some part of professional finance before they reach maturity. Banks can also teach desired social habits this way, for example financial planning and saving. On the other hand, the ever-increasing digitalisation of the younger generations means that they participate in an increasing number of initiatives related to mobile or internet shopping and digital payments made through financial institutions. Topping up mobile phones, shopping in online stores, booking tickets or accommodation usually requires quick cashless payments. The use of banking products or services becomes then a necessity and affects the reduction of financial, environmental and, in extreme cases, social exclusion of young people. Both, Generation Y, i.e. people born in the 1980s and 1990s, who cope very well with novelties, new media and innovative telecommunication solutions, and especially Generation Z (iGen), i.e. people born in the 21st century, who do not know the world without mobile and internet technologies, are very suitable to use digital financial solutions offered by banks.

Due to the increasing interest of banks in the development of offers for young people and the widespread use of banking products and services among people under 26 years, the authors of this work undertook the research with the aim of evaluating the types, preferences and patterns of using banking offers by children, youths and young adults. The authors also evaluated major channels of accessing banking products and services as well as factors determining their choice by the group under consideration. The investigation was also aimed at 
finding out if young people use financial products and services of financial institutions other than banks.

For the purposes of research conducted as a part of the work, the authors adopted two research hypotheses:

- Hl: Level of financial knowledge determines the diversity of banking products used by young people;

- H2: Young people that use banking products are common users of non-banking financial products and services.

Undertaking the research in the mentioned field is justified by a relatively small number of publications related to the topic of banking services for children and young people, as well as classifying this group of people outside the mainstream of banking research despite its prospective nature. Knowledge about conditions and preferences, as well as the effects of using bank products and services, may support banks in offering products better adjusted to age, and preferences, as well as the needs of young people.

\section{Literature review}

Johnson \& Sherraden (2007, pp. 119-145) emphasise that, it is crucial in modem society to have the ability to understand, assess, and act in the best financial interest. Generally, people's behaviour on the financial market as well as access to the financial market offer can be dependent on their age, gender, education, place of residence, social status (Walczak \& Pieńkowska-Kamieniecka, 2018, p. 123), or their wealth (Dziawgo, 2006). Among the young clients of financial institutions, students are the most often examined group. For example, Motlhabane (2017, pp. 98-104) assessed whether the banks' strategies help to attract and retain or deter tertiary students from their businesses. The author examined the banks' need to go beyond expectations in nurturing students as clientele. In another study the aspects, which customers (students) consider when selecting a particular bank or when switching to another one, were presented by Camilleri \& Ellul (2017, pp. 51-63). The study prepared by Foscht et al. (2010, pp. 264-276) examines what determined the youth's choice of banks. Determinants of satisfaction, loyalty, and behavioural intention were primarily affected by satisfaction with employees and services rendered. The results indicate that as young people reach certain milestones, their needs become more multifaceted. Floh \& Treiblmaier (2006, p. 105) in their paper investigated the importance of antecedents of online banking loyalty such as trust, quality of the web site, quality of the service and overall satisfaction. The authors confirmed that service quality has a stronger impact on satisfaction for younger people than for the elderly.

The research area of servicing young people by banks can be considered as important, as young people are a natural group for financial inclusion. The process of financial inclusion has been an area of investigation of some international institutions including The World Bank, which finds young people as the seg- 
ment of population with the lowest usage of financial services (Demirguc-Kunt \& Klapper, 2012). The benefits of the inclusion of children, youths and young adults into using banking services, including an increasing capacity to find employment, undertake entrepreneurship, as well as becoming economically conscious and productive members of society, were presented by the Child \& Youth Finance International and MasterCard (2014). In the investigation of young people, the group under consideration is often analysed as one of several age segments of bank clients. There is also research conducted among students but not directly on children and youths below 18 years old as well as young adults not being students. The general attitude of Poles towards a non-cash economy and the using of banking products among the various age groups including young adults were systematically investigated in the years 2009, 2013, 2016 by Maison (2017). The evaluation of the recognition and image of cooperative banks among students from high school were examined by Perek \& Pawlonka (2014, pp. 71-83). The research showed that cooperative banks are seen by youths as safe, trustworthy but conservative, old fashioned and not for young people. Some other researches were conducted by financial market analysts and public opinion research centres, e.g. according to such institutions young people are relatively difficult to persuade to start using banking products and services, but when they become clients of banks, they usually remain a loyal group (Newseria, 2016). The offers of banks to young people are often characterised by special conditions, e.g. complimentary character and more innovative or beneficial features than standard products for retail clients (Totalmoney.pl, 2016). Also, the using of bank offers (except loans) is not conditioned by creditworthiness or the regular incomes of young people. This may confirm a relatively high potential for the adoption of banking products and services by children, youths and young adults accessed by the internet or smartphones.

\section{Research methods}

For the aims set in the paper, the authors elaborated and conducted a survey with the CAWI technique on a sample of children, youths and young adults (under the age of 26). The research was aimed at obtaining data to assess the reasons, conditions and effects of use of banking products and services by young people. The authors investigated also the types of bank products used and services as well as opinions of the young people on bank servicing. The survey was addressed to a group aged 25 years and below. Such an age was assumed as the upper limit of being young from the perspective of financial institutions, i.e. the age at which clients are able to obtain products or services specially designed for children or youths or products, which are sold free of charge to this age level. There was no lower age limit of respondents, however we assumed that most important would be responses from the people at the age of 13 and more, as that is the threshold of obtaining limited legal ability and hence ability to conduct simple banking operations by children. In fact, a very limited banking offer is 
available for children below the age of 13 and it functions mostly as added functionality of products or services used by their parents. The authors presented aspects of the age of clients in the financial market and the availability of financial products for children, young people and young adults in the article entitled Young people and banking products and services in Poland: fundamental aspects.

The investigation was conducted in the period January-February 2017 with a questionnaire created in the internet application Interankiety.pl. The respondents were asked about filling the application in, through a social media network and internet blog. The applicants were also asked to invite their relatives or friends (under 26) to participate in the research.

The questions in the survey were grouped into three parts, i.e. a general part for all the participants, a part for users of bank products and services and a part for people not experienced in banking. The majority of questions were closeended except the question about the brand of the servicing banks. During the three-week period, in total, 224 questionnaires were collected of which 15 were removed due to lack of answers. Three questionnaires were filled in by children with the help of their parents or other older persons to present the survey in a more accessible way.

For the scientific purposes of the paper the authors used the statistical Chi square test, coefficient of contingency, Spearman's Rho correlation as well as a multivariate backward stepwise logistic regression. The evaluation was performed with IBM SPSS Statistics (ver. 25). The young people being users of banking offers were profiled according to independent variables such as: age $(<18,18-21,22-25)$, gender, education level (primary/gymnasium, secondary/vocational, higher, higher economicl), place of residence (countryside, city $<100 \mathrm{k}$, city $100-500 \mathrm{k}$, city $>500$ ), level of financial knowledge (lack/ poor, general, average, good, very good), source of financial knowledge (parents/friends, TV/books/press, internet, school/college), main access channel (branch, internet, mobile), frequency of using of banking offers (less than monthly, once per month, several times per month, once per week, several times per week, daily), age of starting of using banking products $(<13,13-17$, 18-21, 22-25), bank PKO BP² client (yes, no), user of other than banking financial products (yes, no).

1 The detailed characteristics of the system of education in Poland are provided by Smoczyńska (2014, p. 7).

2 The biggest commercial bank in Poland commonly chosen by young people. 


\section{Results}

\subsection{Analysis of products and services currently used by young people}

Young people participating in the survey were asked to indicate the type of banking products and services they currently use. The respondents could select more than one product or service. The obtained results in general confirmed the common use of the bank's internet service, payment cards, ATMs and current accounts (chart l).

The obtained structure of indications may confirm rather a multi-product approach of the usage of banking offers by young people based on 'typical' products such as accounts, cards and internet servicing (money transfers, checking balance of the account, managing personal finance) ${ }^{3}$. Less common were mobile applications and savings accounts or term deposits. None of the respondents indicated the use of loans, including student credits, which may confirm that the major focus of the mentioned group is on safe and simple products.

Due to a relatively high number of products indicated by respondents, the authors decided to distinguish three generic groups to analyse the profile of their users. The products were classified into: (1) traditional banking (TB) including: current accounts, savings accounts, term deposits; (2) card banking (CB) including: payment cards, ATMs and terminal banking; (3) modern banking (MB) including: internet banking, mobile applications, BLIK payments and email/mobile payments ${ }^{4}$.

Table 1 presents the statistically significant parameters of multivariate backward stepwise logistic regression models describing the use of TB, CB, MB. The testing proved that the use of traditional products depends firstly on the age. The $<18$ age group represents approx. 5.84 times higher chances to be users of TB products than the older group (18-21). Furthermore, clients of other banks than PKO BP present approx. 2 times higher chances of being traditional banking products users. Such results may confirm the innovative character of the biggest Polish commercial bank. Considering the profile of CB users, the logistic regression model shows that women and persons in the age 22-25 are about 4.6 and 311 times more likely to use card banking than men and people under the age of 18. Moreover, the persons with higher and higher economic education level were representing significantly less chances to use card banking than persons with primary and vocational education. Such a phenomenon can be justified not necessarily by the lack of interest in using payment cards or ATMs by

3 The interesting phenomenon is that young people significantly less often indicated the use of a current account than internet banking, payment cards or ATMs, which as a rule, require opening a current account.

${ }^{4}$ Due to a lack of usage of student loans the authors omit this item in dependence analysis. 
highly educated people but rather by using products from the MB group. Such conclusions can be confirmed by the parameters of modelling of MB products where people with high or secondary education are respectively 32 and 12 times more likely to use the offers of banks against people with primary and gymnasium education. The usage of modern banking products is also associated with people declaring their level of financial knowledge as general or good, which represent respectively 20 and 40 times higher chances of using against people with a lack of or poor knowledge. Furthermore, the usage of modern banking is also characteristic for those young people who use primarily internet and mobile access channels in contact with banks (4l and 156 times higher chances than people using a bank branch as the major channel). The analysis of using at least one product from three distinguished groups indicates that the use of traditional and payment card products is dependent in general on the age. In contrary the use of modern banking solutions is determined by formal education level, subjective level of financial knowledge and the access channel.

To investigate the profile of young people using banking products and services, the authors classified respondents into two groups, i.e. focused users (FU) if they were using products only from one group (TB, CB or MB) or multi-products users (MU) if they were using products from all three groups ${ }^{5}$. The results of modelling are presented in table 2.

The logistic regression indicates that among young people the focused users are primarily the children and youths ( $<18$ years), people with a lack of or poor financial knowledge and those using traditional channels of contact with bank, e.g. People in the age 22-25 are approx. 16 times less prone to be focused users than people under 18. People with a subjective good level of financial knowledge have approx. 83 times lower chance to be focused users than people with a lack of or poor knowledge. Those clients who use mobile access channels present more than 6 times lower chances to be focused users (i.e. users of products just from a single product group) than branch users. Against this background multi-products users are primarily young adults in the age 22-25, people evaluating their own knowledge as higher than a lack of or poor knowledge and the clients of other banks than the biggest Polish commercial bank $\mathrm{PKO} \mathrm{BP}$. In case of focused and multi-product users, the highest impact is represented by the level of knowledge and then by the age. Except of the variable $\mathrm{CB}$, the type and the scope of using of banking products is not determined by gender, which may confirm that women and men use bank offers in a similar way. This may also verify that the differences between the genders in using banking products and services among youths and young adults are less significant than the differences in the whole of society confirmed by the research conducted by Walczak \& Pieńkowska-Kamieniecka (2018, pp. 123-132) as well as Polasik \& Wisniewski (2009, pp. 32-35). The place of residence, source

5 The number of multi-products users was 90 and the focused-users 21 . The authors omitted analysis of users of products from two groups. 
of financial knowledge, the age of first adoption of banking offers as well as the usage of other than banking financial products are not determining the use.

\subsection{Analysis of products most frequently used by young people}

Young people that use banking products and services were also asked about the most frequently used (preferred) product or service (chart 2). The most often indicated option was payment card (53\%). The second option was internet banking including money transfers (14\%) and the third, current account (10\%). As the respondents could give just one answer, one could find a vital disparity between payment card and other products and services including internet banking and current accounts. The dominance of payment cards may confirm that young people primarily use bank offers for day-to-day cashless payment operations. Less important is checking account balance, wire money transfers, making operations on bank account or taking cash from ATMs.

The authors used Chi square test, contingency coefficient and Spearman's Rho correlation coefficient to find statistical dependence between the most frequently used products and variables depicted in paragraph 3 . The results are presented in table 3.

The statistical analysis results confirm dependence and positive correlation between payment cards as the most frequently used banking products and access channel, frequency of using banking products and services as well as the age of starting usage of banking offers. Frequency and age of starting using bank products were also statistically significant factors for internet banking. Three completely different factors (education level, subjective level of financial knowledge and place of residence) influenced the indication of current account as the most frequently used banking product.

\subsection{Analysis of main access channels used by young people}

The authors of the paper analysed also channels of access to banking offers preferred by young people (chart 3 ). The highest number of indications in the survey $(76 \%)$ were the Internet, which was more than four times frequently used than mobile phones (18\%) and the stationary branches (6\%). Such structure of answers can be considered as surprising as banks are intensively promoting mobile services as the solutions adjusted to the style of life of young people.

To investigate in more details the use of particular access channels, the authors performed statistical analysis of the dependence between internet banking, mobile applications, stationary branches and the variables depicted in paragraph 3. The authors used Chi square test, coefficient of contingency and Spearman's Rho correlation coefficient. The results are presented in table 4.

The Chi square test and coefficients confirmed the dependence between internet banking channel users and the age, as well as education level. In both cases an increase of the variable has influenced positively, the use of the Inter- 
net as a major access channel. The usage of traditional branches is statistically dependent on gender, age, education level and the frequency of using banking products. Contrary to internet channels an increase of the age and education level as well as being a woman reduces the usage of stationary branches. The strongest negative influence is represented by the frequency of usage of banking offers. The use of mobile applications as the major access channel turned out to have another pattern of dependence. In this case, just the level and source of knowledge got statistical significance ${ }^{6}$. Gender, age, place of residence, frequency of usage of banking products, age of starting bank products adoption, being a $\mathrm{PKO} \mathrm{BP}$ client as well as using products of other financial institutions were not influencing the use of the mobile channel.

\subsection{Analysis of other than banking financial products and services used by young people}

The authors intended also to investigate if young people that use bank products and services are users of offers of financial institutions other than banks. The research revealed that the majority of young people (82\%) uses exclusively the products of banks, which may confirm their financial inclusion primarily throughout the banking sector. Just 15\% of respondents declared using products and services of insurance companies and $2 \%$ declared using products of insurance companies and investment funds companies. Just $1 \%$ declared using just offers of investment funds companies. None of the respondents indicated other types of financial products or services used. Chart 4 presents the structure of the responses.

The insurance products were used exclusively by people having secondary (23\%), high (27\%) or high economic education (50\%). Also, such products were primarily used by the oldest group of young people, i.e. 22-25 years (85\%). The investment fund companies' products were purchased exclusively by people of 22-25 years with high and high economic education level. The analysis of the structure of answers was confirmed statistically by Chi square test, coefficient of contingency and Spearman's Rho correlation coefficient (table 5).

The statistical analysis confirmed that the age, education level, subjective level of financial knowledge as well as the source of financial knowledge (ordered by the level of advancement) are statistically confirmed as influencing the use of other than banking financial products. Similar results are obtained during the analysis of the usage of insurance. Such an effect can be explained by the age requirement to conclude the insurance contract as well as the consciousness of the need and the level of knowledge required to use such (e.g. more complex) financial products. The strongest influence is noted in the case

6 The low negative correlation between the use of mobile banking and source of knowledge (ordered according to the level of accuracy of knowledge passed) is a result of a relatively high number of young adults obtaining knowledge from internet or college/school who do not use mobile banking at all. 
of subjective level of knowledge and then for education level. This may confirm that the usage of non-banking financial products such as insurance must be supported by education, which effectively increases the financial knowledge of young people.

\section{Conclusion}

Young people commonly decide to start using bank products and services, which is confirmed by the share of users of bank offers in the group of persons up to 25 years ( $74 \%$ of the investigated group). In general, children, youths and young adults use many standard products such as payment cards, internet banking, ATMs and current accounts. The statistical analysis of banking products, frequency of their use, access channels as well as other than banking products used, allows one to draw several vital conclusions. Traditional products (accounts) are used primarily by children and youths, while card banking is used primarily by young adults in the age of 22-25. Use of modern and innovative products such as internet banking, mobile applications and mobile payments is determined primarily by the education level, subjective level of financial knowledge as well as the type of main access channels. The level of financial knowledge turned out to have the strongest impact on the diversity of used bank products and services. Such results positively verifies hypothesis $\mathrm{Hl}$.

An analysis of the types and diversity of banking products used by young people indicates that approximately the same number uses modern banking products and payment card products and less users are interested in traditional accounts (current, savings and term deposits). Young people are characterised also by the multi products approach to the adoption of banking offers, i.e. simultaneous usage of modern banking products, payment cards and traditional banking. This group was represented by the highest number of respondents. The lowest number depicted the focused banking product users, i.e. persons using products belonging exclusively to one product group. One should note that despite the common use of various products from various groups, young people rather do not adopt risky products such as loans.

Another important conclusion from the research is that young people as a rule do not use financial products other than banking. Some minor share was gained by insurance companies' products. Such results negatively verify hypothesis $\mathrm{H} 2$.

\section{References}

Camilleri, S.J., \& Ellul, D. (2017). Younger customers' outlooks when selecting and changing a financial services provider: the case of Maltese students. International Journal of Financial Research, 8(2). doi:10.5430/ijfr.v8n2p51. 
Child \& Youth Finance International \& MasterCard Incorporated International (2014). Banking a new generation. Developing responsible retail banking products for children and youth. Retrieved 14.02.2019 from http://www.childfinanceinternational.org.

Demirguc-Kunt, A., \& Klapper, L. (2012). Measuring financial inclusion: the Global Findex Database. The World Bank Policy Research Working Paper, 6025 .

Dziawgo, L. (2006). Private banking. Bankowość dla zamożnych klientów. Warszawa: Wolters Kluwer.

Floh, A., \& Treiblmaier, H. (2006). What keeps the e-banking customer loyal? A multi-group analysis of the moderating role of consumer characteristics on e-loyalty in the financial service industry. Journal of Electronic Commerce Research, 7(2). doi:10.2139/ssrn.2585491.

Foscht, T., Maloles, III, C., Schloffer, J., Chia, S-L., \& Sinha, I., (2010). Banking on the youth: the case for finer segmentation of the youth market. Young Consumers, 11(4). doi:10.1108/17473611011093907.

Johnson, E., \& Sherraden, M.S. (2007). From financial literacy to financial capability among youth. Journal of Sociology and Social Welfare, 34(3).

Maison, D. (2017). Postawy Polaków wobec obrotu bezgotówkowego. Raport z badania 2016 i analiza porównawcza z danymi z 2009 i 2013 roku. Retrieved 14.02.2019 from https://www.nbp.pl.

Motlhabane, K.L. (2017). Going beyond expectations: banks strategies attract and retain or deter tertiary students' clientele. Banks and Bank Systems, 12(1). doi:10.21511/bbs.12(1-1).2017.01.

Newseria. (2016). Mtodzi klienci banków bardziej lojalni i mniej wymagający. Retrieved 14.02.2019 from https: / /biznes.newseria.pl.

Perek, A., \& Pawlonka, T. (2014). Rozpoznawalność banków spółdzielczych w segmencie młodych konsumentów. Zeszyty Naukowe SGGW. Ekonomika i Organizacja Gospodarki Żywnościowej, 106. doi:10.22630/EIOGZ.2014.106.16.

Polasik, M. \& Wisniewski, T.P. (2009). Empirical analysis of internet banking adoption in Poland. International Journal of Bank Marketing, 27(1). doi:10.1108/02652320910928227.

Smoczyńska, A. (Ed.). (2014). The system of education in Poland. Warsaw: Foundation for the Development of the Education System.

Totalmoney.pl (2016). Oferta banków skierowana do dzieci i mtodzieży. Retrieved 14.02.2019 from https://www.totalmoney.pl.

Walczak, D., \& Pieńkowska-Kamieniecka, S. (2018). Gender differences in financial behaviours. Engineering Economics, 29(1). doi:10.5755/j01. ee.29.1.16400. 


\section{Acknowledgements}

Author contributions: authors have given an approval to the final version of the article. Authors contributed to this work as follows: M.B. and D.K. developed the concept and designed the study, M.C. collected the data, M.B. and D.K. analysed and interpreted the data, M.B. prepared draft of article, D.K. revised the article critically for important intellectual content.

Funding: this research was funded by the Nicolaus Copernicus University in Torun, Faculty of Economic Sciences and Management, Department of Finance Management statutory sources.

Note: the results of this study were presented at 25th EBES Conference (May, 23-25, Berlin, Germany). Some part of the data was used by Malwina Chojnacka in her master thesis. 


\section{Appendix}

Table 1.

Multivariate backward stepwise logistic regression models of using traditional banking, card banking and modern banking

\begin{tabular}{|c|c|c|c|c|c|c|}
\hline Specification & B & $\begin{array}{c}\text { St. } \\
\text { error }\end{array}$ & $P$-value & $\begin{array}{c}\operatorname{Exp}(\mathrm{B}) \\
(\mathrm{OR})\end{array}$ & $\begin{array}{c}95 \% \\
\text { CI LL } \\
\end{array}$ & $95 \%$ CI UL \\
\hline \multicolumn{7}{|l|}{$\mathrm{TB}, 1=113,0=41$} \\
\hline age $<18$ & - & - & 0.004 & - & - & - \\
\hline age 18-21 & - & - & 0.036 & 0.171 & 0.033 & 0.0888 \\
\hline PKO BP user & -0.719 & 0.401 & 0.073 & 0.487 & 0.222 & 1.069 \\
\hline constant & 2.146 & 0.801 & 0.007 & 8.548 & - & - \\
\hline Nagelkerkeg $\mathrm{R}^{2}$ & \multicolumn{6}{|c|}{0.120} \\
\hline Cox Snell R² & \multicolumn{6}{|c|}{0.082} \\
\hline Hosmer Lemeshow test $p$-value & \multicolumn{6}{|c|}{0.991} \\
\hline \multicolumn{7}{|l|}{$\mathrm{CB}, 1=133,0=21$} \\
\hline gender: female & 1.529 & 0.874 & 0.080 & 4.613 & 0.831 & 25.599 \\
\hline age $<18$ & - & - & 0.050 & - & - & - \\
\hline age $22-25$ & 5.741 & 2.458 & 0.020 & 311.282 & 2.517 & $38,503.088$ \\
\hline education level: primary/gymnasium & - & - & 0.098 & - & - & - \\
\hline education level: higher & -6.268 & 2.685 & 0.020 & 0.002 & 0.000 & 0.366 \\
\hline education level: higher economic & -5.053 & 2.718 & 0.063 & 0.006 & 0.000 & 1.316 \\
\hline level of financial knowledge: lack/poor & - & - & 0.047 & - & - & - \\
\hline frequency of using of banking offers: less than monthly & - & - & 0.041 & - & - & - \\
\hline Nagelkerkeg $\mathrm{R}^{2}$ & \multicolumn{6}{|c|}{0.537} \\
\hline Cox Snell R $R^{2}$ & \multicolumn{6}{|c|}{0.295} \\
\hline Hosmer Lemeshow test $p$-value & \multicolumn{6}{|c|}{0.445} \\
\hline \multicolumn{7}{|l|}{$\mathrm{MB}, 1=131,0=41$} \\
\hline education level: primary/gymnasium & - & - & 0.019 & - & - & - \\
\hline education level: secondary & 3.107 & 1.041 & 0.003 & 22.359 & 2.907 & 171.953 \\
\hline education level: higher & 2.812 & 1.116 & 0.012 & 16.638 & 1.867 & 148.272 \\
\hline education level: higher economic & 3.544 & 1.373 & 0.010 & 34.599 & 2.347 & 510.072 \\
\hline level of financial knowledge: lack/poor & - & - & 0.010 & - & - & - \\
\hline level of financial knowledge: general & 2.415 & 0.973 & 0.013 & 11.191 & 1.661 & 75.408 \\
\hline level of financial knowledge: average & 1.883 & 0.845 & 0.026 & 6.575 & 1.254 & 34.473 \\
\hline level of financial knowledge: good & 4.976 & 1.638 & 0.002 & 144.889 & 5.850 & $3,588.373$ \\
\hline main access channel: branch & - & - & 0.005 & - & - & - \\
\hline main access channel: internet & 3.718 & 1.286 & 0.004 & 41.168 & 3.310 & 512.072 \\
\hline main access channel: mobile & 5.047 & 1.623 & 0.002 & 155.556 & 6.467 & $3,742 \cdot 0 \cdot 15$ \\
\hline constant & -6.268 & 1.691 & $<0.001$ & 0.002 & - & - \\
\hline Nagelkerkeg $R^{2}$ & \multicolumn{6}{|c|}{0.510} \\
\hline Cox Snell R² & \multicolumn{6}{|c|}{0.291} \\
\hline Hosmer Lemeshow test $p$-value & \multicolumn{6}{|c|}{0.763} \\
\hline
\end{tabular}

Notes:

Models present only statistically significant variables except constant at $\alpha=0.1, N=154$.

Source: Own study based on a survey. 
Table 2.

Multivariate backward stepwise logistic regression models of focused and multiproduct users

\begin{tabular}{|c|c|c|c|c|c|c|}
\hline Specification & $\mathrm{B}$ & St. Error & $P$-value & $\operatorname{Exp}(\mathrm{B})(\mathrm{OR})$ & 95\% CI LL & $95 \%$ CI UL \\
\hline \multicolumn{7}{|l|}{ FU, $1=21,0=133$} \\
\hline age $<18$ & - & - & 0.013 & - & - & - \\
\hline age $22-25$ & -2.803 & 1.030 & 0.006 & 0.061 & 0.008 & 0.458 \\
\hline level of financial knowledge: lack/poor & - & - & 0.11 & - & - & - \\
\hline level of financial knowledge: general & -2.067 & 1.001 & 0.039 & 0.127 & 0.018 & 0.899 \\
\hline level of financial knowledge: average & -2.292 & 0.902 & 0.011 & 0.101 & 0.017 & 0.591 \\
\hline level of financial knowledge: good & -4.413 & 1.554 & 0.005 & 0.012 & 0.001 & 0.255 \\
\hline main access channel: branch & - & - & 0.011 & - & - & - \\
\hline main access channel: internet & -3.791 & 1.315 & 0.004 & 0.23 & 0.002 & 0.297 \\
\hline main access channel: mobile & -4.161 & 1.482 & 0.005 & 0.16 & 0.001 & 0.285 \\
\hline constant & 5.052 & 1.555 & 0.001 & 156.343 & - & - \\
\hline Nagelkerkeg R2 & \multicolumn{6}{|c|}{0.501} \\
\hline Cox Snell R2 & \multicolumn{6}{|c|}{0.275} \\
\hline Hosmer Lemeshow test $p$-value & \multicolumn{6}{|c|}{0.765} \\
\hline \multicolumn{7}{|l|}{$\mathrm{MU}, \mathrm{l}=90,0=64$} \\
\hline age $<18$ & - & - & 0.008 & - & - & - \\
\hline age $22-25$ & 1.368 & 0.669 & 0.041 & 3.929 & 1.058 & 14.587 \\
\hline level of financial knowledge: lack/poor & - & - & 0.016 & - & - & - \\
\hline level of financial knowledge: general & 3.110 & 1.119 & 0.005 & 22.424 & 2.503 & 200.922 \\
\hline level of financial knowledge: average & 3.378 & 1.104 & 0.002 & 29.304 & 3.370 & 254.827 \\
\hline level of financial knowledge: good & 3.692 & 1.106 & 0.001 & 40.134 & 4.589 & 351.022 \\
\hline level of financial knowledge: very good & 2.717 & 1.192 & 0.023 & 15.141 & 1.464 & 156.642 \\
\hline PKO BP user & -0.762 & 0.396 & 0.054 & 0.467 & 0.215 & 1.013 \\
\hline constant & -3.381 & 1.213 & 0.005 & 0.034 & - & - \\
\hline Nagelkerkeg R2 & \multicolumn{6}{|c|}{0.295} \\
\hline Cox Snell R2 & \multicolumn{6}{|c|}{0.219} \\
\hline Hosmer Lemeshow test $p$-value & \multicolumn{6}{|c|}{0.823} \\
\hline
\end{tabular}

Notes:

Models present only statistically significant variables except constant at $\alpha=0.1, N=154$.

Source: Own study based on a survey. 
Table 3.

Variables influencing using of payment cards, internet banking and current accounts

\begin{tabular}{llrrr}
\hline \multicolumn{1}{c}{ Variables } & & Payment card & Internet banking & Current account \\
\hline \multirow{2}{*}{ education level } & $p$-value & - & - & 0.040 \\
& C/Rho & - & - & $0.226 / 0.213$ \\
level of financial knowledge & $p$-value & - & - & 0.021 \\
& C/Rho & - & - & $0.264 / 0.207$ \\
place of residence & $p$-value & - & - & $0.226 / 0.130$ \\
& C/Rho & - & - & - \\
main access channel & $p$-value & 0.033 & - & - \\
& C/Rho & $0.206 / 0.125$ & 0.004 & - \\
frequency of using of banking offers & $p$-value & 0.004 & 0.041 & - \\
C/Rho & $0.319 / 0.187$ & $0.318 /-0.087$ & - \\
age of starting of using banking products & p-value & 0.009 & 0.011 & - \\
& C/Rho & $0.264 / 0.251$ & $0.260 /-0.264$ & - \\
\hline
\end{tabular}

Notes:

The table presents only variables which are statistically significant at $\alpha=0.05, N=154$.

Source: Own study based on a survey.

Table 4.

Variables influencing using of internet, mobile phones and branches

\begin{tabular}{|c|c|c|c|c|}
\hline Variables & & Internet & Mobile phone & Branch \\
\hline \multirow{2}{*}{ gender } & $p$-value & - & - & 0.010 \\
\hline & C/Rho & - & - & $0.202 /-0.206$ \\
\hline \multirow{2}{*}{ age } & $p$-value & 0.008 & - & $<0.001$ \\
\hline & C/Rho & $0.242 / 0.180$ & - & $0.376 /-0.277$ \\
\hline \multirow{2}{*}{ education level } & $p$-value & 0.025 & - & 0.002 \\
\hline & C/Rho & $0.239 / 0.131$ & - & $0.296 /-0.200$ \\
\hline \multirow{2}{*}{ level of financial knowledge } & $p$-value & - & 0.038 & - \\
\hline & C/Rho & - & $0.249 / 0.060$ & - \\
\hline \multirow{2}{*}{ source of financial knowledge } & $p$-value & - & 0.033 & - \\
\hline & C/Rho & - & $0.231 /-0.002$ & - \\
\hline \multirow{2}{*}{ frequency of using of banking offers } & $p$-value & - & - & $<0.001$ \\
\hline & C/Rho & - & - & $0.431 /-0.316$ \\
\hline
\end{tabular}

Notes:

$N=154$.

Source: Own study based on a survey. 
Table 5 .

Variables influencing using of other than banking financial products and services

\begin{tabular}{llrr}
\hline \multicolumn{1}{c}{ Variables } & \multicolumn{1}{c}{ Other } & \multicolumn{1}{c}{ Insurance } \\
\hline \multirow{2}{*}{ age } & $p$-value & 0.027 & 0.036 \\
& C/Rho & $0.212 / 0.215$ & $0.203 / 0.206$ \\
education level & $p$-value & 0.005 & 0.012 \\
& C/Rho & $0.277 / 0.285$ & $0.259 / 0.266$ \\
level of financial knowledge & $p$-value & $<0.001$ & $<0.001$ \\
& C/Rho & $0.347 / 0.317$ & $0.342 / 0.306$ \\
source of financial knowledge & -value & 0.035 & - \\
& C/Rho & $0.230 / 0.197$ & - \\
\hline
\end{tabular}

Notes:

$N=154$.

Source: Own study based on a survey.

\section{Chart 1.}

Bank products and services used currently by young people (in \%)

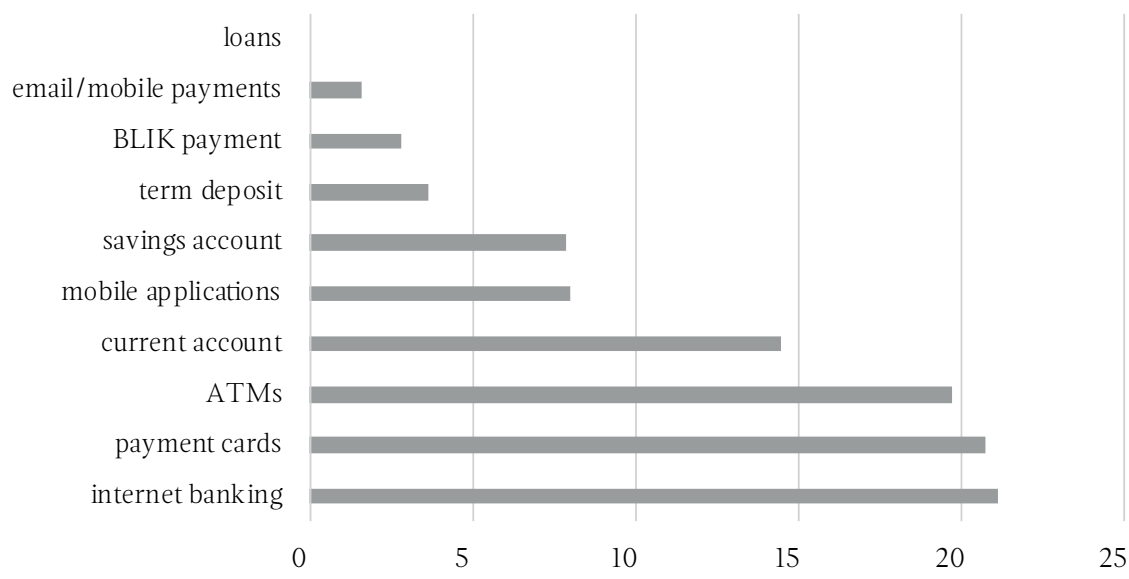

Notes:

$N=154$, multiple choice.

Source: Own study based on a survey. 


\section{Chart 2.}

Bank products and services most frequently used by young people (in \%)

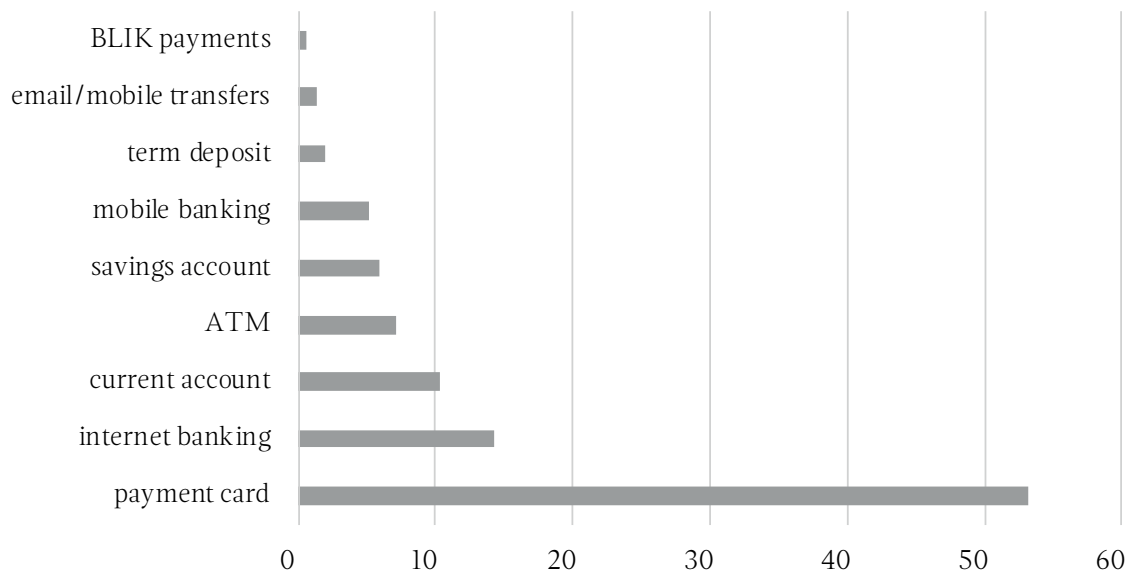

Notes:

$N=154$, single choice.

Source: Own study based on a survey.

\section{Chart 3.}

Preferred access channels to bank products and services (in \%)

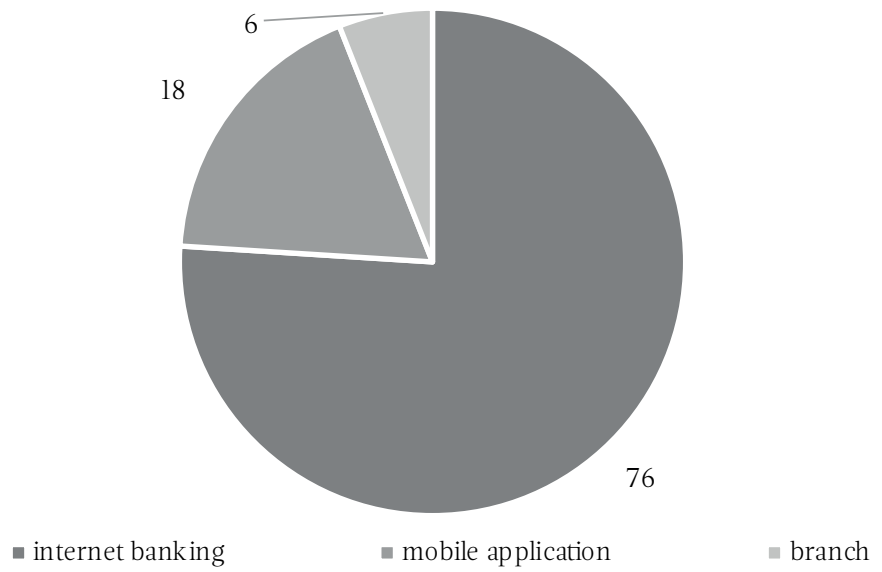

Notes:

$N=154$, single choice.

Source: Own study based on a survey. 


\section{Chart 4.}

Products and services of other financial institutions used by young people (in \%)

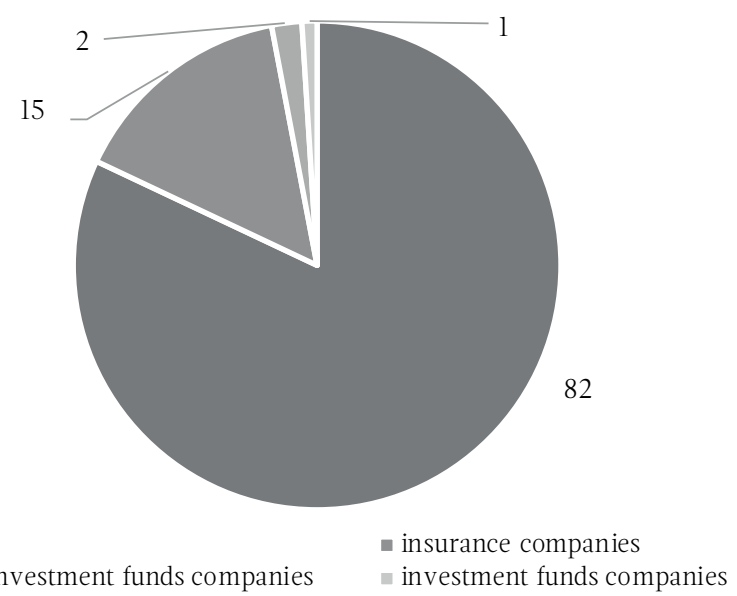

- not used

- insurance and investment funds companies
- insurance companie

- investment funds companies

Notes:

$N=154$, single choice.

Source: Own study based on a survey. 